\title{
Ética Calvinista, Idealismo e Revolução: Carlyle e a Crítica da Economia Vitoriana
}

\author{
Rogério Arthmar
}

Professor Adjunto do Departamento de Economia

da Universidade Federal do Espírito Santo - UFES

\section{RESUMO}

O artigo versa sobre a doutrina econômica e social de Thomas Carlyle, célebre autor escocês do século dezenove. Inicialmente, são revistos alguns aspectos essenciais da sociedade e do capitalismo industrial na Inglaterra durante o período. Resgatam-se, a seguir, as influências religiosas e filosóficas do pensamento social de Carlyle. Após, discutem-se sua concepção da história e a versão da Revolução Francesa por ele formulada para, na seqüência, introduzir sua crítica da economia vitoriana. Ao final, avaliam-se os avanços e contradições de sua teoria social.

\section{PALAVRAS-CHAVE}

calvinismo, revolução, capitalismo

\section{ABSTRACT}

This paper deals with the economic and social doctrine of Thomas Carlyle, famous Scottish writer from the nineteenth century. Firstly, we review some basic aspects of England's society and her industrial capitalism at that time. Next, the religious and philosophical influences on Carlyle's social thought are retrieved. After that, we discuss both his approach to history and his version of the French Revolution for, in the sequence, introducing his critique of the Victorian economy. In the end, we evaluate the advances and contradictions of his social theory.

KEY WORDS

calvinism, revolution, capitalism

JEL Classification

$B / 0, B / 9$ 


\section{INTRODUÇÃO}

"Nenhum homem de letras recente ocupou na Inglaterra posição comparável àquela que, por pelo menos um quarto de século, foi sua sem contestação, e autores de todos os gêneros e escolas lamentarão a perda de seu venerado mestre.” (MacDONNEL, 1881, p. 692). Com essas palavras solenes, publicadas pelo London Times em seu obituário de Thomas Carlyle, no ano de 1881, a comunidade britânica despedia-se de um dos mais notáveis pensadores de sua história moderna. Nascido na pequena localidade de Ecclefechan, Escócia, em 4 de dezembro de 1795, Carlyle é educado em escolas privadas e religiosas, freqüenta a Universidade de Edimburgo, e após o término de seus estudos ministra aulas particulares de astronomia e matemática por algum tempo. Em 1826, casa-se com Jane Welsh, e no ano seguinte o casal retira-se para uma fazenda em Craigenputtock, lugarejo solitário na Escócia, onde residem até 1834, quando, cansados do isolamento, mudam-se definitivamente para Chelsea, nos arredores de Londres. A partir daí, Carlyle integra-se aos círculos intelectuais londrinos, tornando-se amigo de John Stuart Mill, Harriet Martineau, John Sterling, Henry Wadsworth, entre uma variedade de literatos, editores e políticos da cidade. À medida que os escritos de Carlyle vêm a público, sua fama e influência projetam-se às alturas, conquistando seguidores como Charles Dickens, John Ruskin, James Froude, entre tantos mais, a ponto de um de seus biógrafos destacar terem todas “... as grandes estrelas do firmamento literário vitoriano caido na órbita de Carlyle em determinado momento.”(HEFFER, 1996, p. 25).

Qualificado por alguns como retrógrado e reacionário (YOUNG, 1927, p. 328-40), por outros como autêntico revolucionário (PECKHAM, 1970, p. 44-83 e ROSENBERG, 1974, p. 200-3), Carlyle deixou extensa produção nas áreas da literatura, da história, da política e da filosofia, em tal magnitude que a compilação de seus textos viria a perfazer mais de trinta volumes. ${ }^{1}$ Em meio a tamanha amplitude de material, não causa surpresa que, até os dias de hoje, se busque decifrar o verdadeiro sentido da contribuição do "profeta de Chelsea" - como veio ele a ser nominado à época - aos diversos campos do conhecimento com os quais se envolveu. Nesse sentido, o presente artigo tem o objetivo específico de recuperar as principais idéias de Carlyle no tocante à realidade econômica e social da Inglaterra do século dezenove, desenvolvidas ao longo do intervalo compreendido entre os anos de 1829 e 1943, quando publica, respectivamente, o artigo Signs of the times e o livro Past and present, fase reconhecidamente mais criativa de sua carreira. Para esse fim, traça-se, inicialmente, breve painel da sociedade vitoriana para, na seqüência, investigarem-se as origens religiosas e filosóficas do pensamento do autor escocês. Adiante, é apresentada a versão de Carlyle para a Revolução Francesa, a qual serve de prelúdio para a análise, na seção seguinte, de sua crítica da economia industrial britânica. Nas consideraçôes finais, avalia-se sua teoria social no

1 Para descrição abrangente da diversidade de avaliações sobre o homem e sua obra, desde o final do século dezenove, consulte-se a Introdução à biografia de Carlyle redigida por HEFFER (1996, p. 1-26). 
que se refere à atuação política das massas e ao caráter do processo histórico sob o capitalismo.

\section{A INGLATERRA DE CARLYLE}

Quando o jovem Carlyle deixa Edimburgo em visita a Londres, no ano de 1824, depara-se com cenário desolador para um camponês das terras altas. A estadia provoca-lhe intenso mal-estar, somente aliviado pelo rápido retorno ao bucolismo agrário de sua Escócia natal. (YOUNG, 1927, p. 50). Tal sensação não era incomum aos que, pela primeira vez, aportavam à cidade. $\mathrm{O}$ francês Jules Valles, ali exilado anos depois, registraria numa série de artigos sua impressão aterradora sobre a metrópole. Num deles, comenta: "A rua de Londres é enorme e vazia - é tão muda como uma fileira de túmulos -, ou então, repleta de carne humana, entulhada de veículos, cheia a ponto de forçar os muros", complementando, a seguir: "E os pobres! Espetáculo cujo horror o nevoeiro e a lama de Londres, por mais espessos, não conseguem ocultar.” (CHARLOT; MARX, 1993, p. 40). Situação semelhante vivenciavam outras localidades industriais do país, como Liverpool, Birmingham, Manchester etc., atingidas por desordenado crescimento demográfico durante as primeiras décadas do século dezenove. Conforme relato de um historiador moderno, os distritos manufatureiros da Inglaterra daquele tempo ganharam renome por sua “... superpopulação, péssimas condições sanitárias e arrepiante fuligem. A 'cidade' deixara de significar o apogeu da organização civil; para os poetas, sobretudo, ela veio a denotar egoismo e maldade." (RICKWORD, 1982, p. 21). A reação de Carlyle, portanto, não era isolada ou fruto exclusivo de uma formação provincial: refletia, mais propriamente, espanto compreensível ante um mundo desconhecido e, sob todos os aspectos, lúgubre, a erigir-se na esteira dos avanços da Revolução Industrial.

A consolidação a passos largos da ordem capitalista na Inglaterra no curso do século dezenove, motivo de perplexidade para Carlyle e seus contemporâneos, faz-se acompanhar por acentuado declínio nas atividades tradicionais do país, particularmente a agricultura e as manufaturas domésticas, sobrepujadas pela produção mecanizada em larga escala. Conjuntamente, verifica-se expansão sem precedentes nas taxas de incremento demográfico, com a população total do reino passando de 10,6 milhões de habitantes em 1801 para 20,8 milhôes em 1851. Nesse contexto, as enclosures, a concentração industrial e o agrupamento de massas de trabalhadores em imensas unidades fabris tornam o país essencialmente urbano. Acentua-se, com isso, a concentração da renda. Os salários mal atendem às necessidades elementares das famílias operárias, enquanto a pobreza assume contornos dramáticos. Numa palavra, a era vitoriana testemunha a plena liberação das violentas energias do capitalismo industrial britânico, quando a nação ingressa em processo inédito, e doloroso, de crescimento sustentável de sua riqueza 
material. (DEANE; COLE, 1969, p. 98-240, SUPPLE, 1978a, p. 49-69 e RICKWORD, 1982, p. 13-23).

No plano político, uma sucessão de reformas busca acomodar as novas forças sociais que se constituem. Vencida a etapa repressiva comandada pelo antijacobinismo Tory do início do século, toma impulso a denúncia dos privilégios e da incompetência da aristocracia agrária em dirigir o país. No ano de 1832, mudança constitucional estende o direito de voto às classes médias em ascensão. Ao final da década, a insatisfação dos trabalhadores nos centros industriais conflui para o Chartism, fracassado movimento popular visando a extensão do sufrágio às categorias excluídas de representação parlamentar. Adiante, contudo, o progressivo sentimento público em favor do alargamento das garantias civis leva à reforma de 1867, quando o acesso às urnas é facultado, enfim, aos assalariados urbanos. Paralelamente, revogam-se, ainda, as Corn Laws, criam-se as escolas públicas e novas universidades, regulamenta-se o trabalho fabril, profissionaliza-se a burocracia estatal, instituem-se as administrações municipais etc. Esse contínuo processo de modernização da sociedade britânica viu-se grandemente favorecido, de uma parte, pela ampla difusão da doutrina metodista, ${ }^{2}$ com sua pregação em prol das boas obras e, de outra, pelo crescente oportunismo das classes governantes, as quais, como assinalou certo estudioso do período, “... acostumaram-se com a mudança como condição normal da vida politica, ao invés de considerá-la o fim de todas as disputas." (TREVELYAN, 1947, p. 656; veja-se, também, SUPPLE, 1978b, p. 90-119 e HIMMELFARB, 1995, p. 275-99).

Todos esses fatos haveriam de exercer profundo abalo na espiritualidade da Inglaterra vitoriana. A contradição entre a aceitação literal da mensagem bíblica e a recomendação de engajamento missionário em questôes sociais, pilares do metodismo vitoriano, não falharia em despertar fundadas dúvidas nas mentes mais esclarecidas. Como aceitar passivamente, perguntava a si o homem da época, que sua existência somente importasse por ser a preparação para a próxima, numa confluência histórica em que a ação e a engenhosidade humanas mostravam-se capazes de realizações inimagináveis na transformação do mundo? Uma série de livros e ensaios brotaria no correr do século contestando os cânones da fé cristã, enquanto os contínuos progressos da ciência nos campos da geologia, da biologia e da paleontologia não tardariam a descortinar novo panorama para a evolução do Homem e da Natureza, impossível de ser conciliado com os insondáveis desígnios do Altíssimo. (MURPHY, 1955, p. 800-17, ALTHOLZ, 1976, p. 59-76 e BURROW, 1978, p. 153-76). Na descrição de um intérprete dos acontecimentos:

2 Movimento religioso criado na Inglaterra em 1739 pelos irmãos John e Charles Wesley e o pregador George Whitfield, do qual se originaram, posteriormente, numerosas ramificaçóes. Tomando as Escrituras como fonte exclusiva de sua crença, os Metodistas reafirmam os dogmas da Santíssima Trindade e da divindade de Cristo, estendendo a todos a possibilidade de salvação eterna por meio de cooperação ativa com Deus no exercício da fé, bem como pela prática de caridade e da reforma social. 
"Em uma de suas facetas, a história Vitoriana é a narrativa da mentalidade inglesa empregando a energia proporcionada pela convicção Evangélica [metodista] de modo a libertar-se dos grilhões que o próprio Evangelismo havia imposto sobre os sentidos e o intelecto; sobre a diversão, os prazeres e a arte; sobre a curiosidade, a critica e a ciência." (YOUNG, 1960, p. 5).

\section{RAÍZES RELIGIOSAS E FILOSÓFICAS DE CARLYLE}

Em 1832, ao receber a notícia do falecimento de seu pai, Carlyle redige extensas notas sobre as lições com ele aprendidas durante a infância. James Carlyle, pedreiro, possuía temperamento rude e circunspecto, ocasionalmente colérico, dedicado por inteiro ao trabalho e, sobretudo, devoto. Tendo na Bíblia sua única leitura, criara os filhos no mais austero rigor puritano, ${ }^{3} \mathrm{sem}$, contudo, medir sacrifícios em garantir-lhes educação formal. "A religião era a Estrela Guia de meu Pai", declara Carlyle, recordando, a seguir, a conviç̧ão paterna de que "... o homem fora feito para trabalhar, não para especular, sentir ou sonbar." Sobre os camponeses presbiterianos de seu pequeno vilarejo, Carlyle confessa terem sido eles “... a benção e salvação de muitos; em mim a influência de sua crença, enviada dos céus, ainda subsiste.” Nesse ambiente desprovido de emoções, quase monástico, sob o cenho autoritário da onipresente figura paterna, se entalha a personalidade do jovem Carlyle, que acabaria por reconhecer no pai “... o sólido alicerce sobre 0 qual minha [vida] viria a nascer e se constituir.” ([1832] 1970, p. 515-52).

Na Universidade de Edimburgo, para onde é enviado ainda adolescente com o propósito de tornar-se pastor, a curiosidade indomável de Carlyle o conduz muito além das liçôes sobre Divindade. Filosofia grega, história romana, Iluminismo, tratados científicos, nada parece suficiente para abrandar sua voracidade de saber. O impacto dessas luzes sobre o pensamento do jovem estudante, no entanto, seria avassalador. Seu ceticismo avulta à medida que folheia avidamente obra após obra de que lança mão, a ponto de abjurar o próprio Cristianismo em que fora educado. (SYMONS, 1952, p. 34-7 e HEFFER, 1996, p. 40-5). "Para mim, o Universo estava desprovido de toda Vida,

3 A doutrina calvinista professa a crença na autoridade suprema da Bíblia, no poder de Deus e na necessidade de uma vida austera e ética, ressaltando, em acréscimo, como seus pontos fundamentais, a contaminação do homem pelo Pecado Original e o conceito de eleição divina para a salvação individual. O movimento puritano, por sua vez, busca construir um calvinismo militante, purificado de todos os ritos e dogmas papistas, com ênfase numa vida disciplinada, voltada a Deus e com ativa missão evangelizadora. Já o presbiterianismo, de origem calvinista e puritana, consiste num sistema de congregaçóes regidas por seus respectivos conselhos de ministros e devotos organizados em nível local e provincial, os presbitérios, subordinados, por sua vez, a uma Assembléia Geral da Igreja. 
Propósito ou Arbitrio" ([1833] 1915, p. 28), diria ele, posteriormente, no livro Sartor Resartus, espécie de autobiografia psíquica de sua juventude.

Não obstante a aflição de espírito e a renúncia à carreira ministerial ao término de seus estudos teológicos - para desapontamento de seu pai - Carlyle carregaria consigo, até o fim de seus dias, os valores essenciais da ética puritana absorvidos na infância. Ao longo de sua obra, além da exaltação recorrente de virtudes como estoicismo, sinceridade, devoção e silêncio, tão características do Antigo Testamento, destacam-se, acima dessas, duas posturas fundamentais de extração calvinista: o desprezo pelo pensamento abstrato e a glorificação da iniciativa pessoal. (GOODWIN, 1905 e HARROLD, 1936). "O homem existe neste mundo não para questionar, mas para trabalhar", sentencia Carlyle em Characteristics, artigo publicado em $1831 .{ }^{4} \mathrm{O}$ peso da herança religiosa paterna viria a se manifestar, igualmente, em seu estilo literário peculiar - apoiado na oratória dos antigos profetas hebreus -, repleto de metáforas, de menções às forças naturais e de advertências sobre os descaminhos da sociedade rumo à tragédia coletiva. (PERRY, 1915, p. 40-59, HOLLOWAY, 1965, p. 21-47 e LANDOW, 1986).

A tormenta existencial do jovem Carlyle, desgostoso com a perspectiva de um mundo inteiramente materialista, somente encontraria alívio em sua descoberta dos filósofos e escritores românticos alemães, os quais se constituiriam a segunda influência decisiva na formação de sua cosmogonia. Em Goethe, por quem cultivava imensa admiração, e outros novelistas e poetas como Schiller, Richter e Novalis, identifica Carlyle preocupação em alçar o indivíduo a um plano superior ao da realidade sensível, a "Idéia Divina”, em franca reação contra o racionalismo ateísta do Iluminismo. Na perseverança, na renúncia às ambições materiais e na atividade criativa, Goethe e seus colegas românticos identificavam os atributos necessários ao aperfeiçoamento das qualidades morais e estéticas capazes de superar o pessimismo e a descrença, fazendo aflorar, assim, a clareza interior ou realidade transcendental.

Já no idealismo filosófico de Kant e Fichte, Carlyle julga encontrar a fórmula para sua restauração espiritual com base na fundamentação metafísica da existência de Deus. Uma vez que toda experiência ligada ao mundo material estaria radicada em conceitos puramente mentais, argumentavam esses pensadores, abrir-se-ia, com isso, a possibilidade de um conhecimento superior, oriundo da necessidade inata de crença no "Ente Divino” e na imortalidade da alma. (IKELER, 1972, p. 72-104 e VIDA, 1993, p. $77-$ 128). Em Sartor Resartus, o Carlyle incrédulo, renascido pelos ensinamentos da filoso-

4 Em verdade, essa posição extremada de Carlyle coadunava-se inteiramente com a tendência ao antiintelectualismo prevalecente entre as classes altas no período vitoriano, derivada da preferência das elites por considerações de ordem prática, relacionadas ao mundo dos negócios, bem como da forte oposição da influente hierarquia religiosa a qualquer tipo de divagação filosófica que pudesse gerar dúvida sobre a fé cristã (cf. HOUGHTON, 1952). 
fia alemã, cede lugar ao crente: "O Universo não é morto e nem endemoniado, cemitério de espectros, mas, sim, divino, Celestial.” ([1833] 1915, p. 34-5).

Durante seu longo retiro em Craigenputtock, Carlyle dedica-se inteiramente à tradução e crítica da literatura alemã contemporânea, bem como à redação de Sartor Resartus. (SYMONS, 1952, p. 100-126 e HEFFER, 1996, p. 88-125). Em 1832, no entanto, o falecimento de seu pai opera completa reviravolta nas intenções do profeta. Doravante, ele não mais se envolve com dilemas espirituais de teor individual. Clama mais alto, em sua consciência, a antiga lição paterna, empurrando-o para o embate obstinado com o concreto, com a realidade dos homens. Brandindo em uma mão o rígido calvinismo escocês e, na outra, o reluzente idealismo alemão, Carlyle decide, de forma inexorável, derramar todo o arrojo de sua pena nos escritos de cunho histórico, político e social. (IKELER, 1972, p. 117-48 e HEFFER, 1996, p. 88-125). E, a partir desse novo rumo em sua carreira, marcado por sua mudança para Londres e o contato direto com a efervescência política da metrópole, é que logrará ele incrustar seu nome, enfim, no tão ambicionado panteão dos grandes homens de letras da língua inglesa.

\section{HISTÓRIA E REVOLUÇÃO}

Em 1830, no ensaio On history, Carlyle investe contra a pretensão Iluminista, então largamente difundida, de construção de uma história científica, subordinada a certo princípio geral capaz de evidenciar, no passado, os diversos estágios evolutivos do homem moderno. (BRYSON, 1943, p. 78-84). Na avaliação de Carlyle, nada poderia ser mais errôneo. $\mathrm{O}$ apelo à experiência como forma de justificar a validade de uma natureza humana imutável padeceria, primeiramente, da impossibilidade de resgatar-se a miríade de fatos e biografias soterradas no passado e, segundo, da diversidade de interpretações pessoais sobre um mesmo acontecimento. "Para Newton e para seu cão Diamond, que dois universos tão diferentes!” (1837, p. 40), exclamaria mais tarde. Leis, constituiçôes, batalhas, conspirações, comumente reputados fatos grandiosos e cardinais, não passariam, a rigor, de meras "brigas de taverna". Por mais importantes que parecessem ser, logo submergiriam na corrente inexorável do tempo. Antes, a verdadeira história transcorreria naqueles recônditos normalmente omitidos pela escrita e invisíveis ao olhar turvo dos historiadores. No labor interminável e silencioso do homem comum do "marinheiro fenício", do "pedreiro italiano" e do "ferreiro saxão" - em sua luta obstinada pelo domínio da Natureza, aí, nesses braços esquecidos, é onde o calvinista Carlyle identifica a fonte perene da genuína vida social das nações: "Quando o carvalho é abatido", observa ele, "toda a floresta ressoa; mas, ao mesmo tempo, centenas de suas sementes são plantadas sem ruido por uma tênue brisa." ([1830] 1970, p. 51).

5 Essa e as demais traduções, com exceção dos trechos extraídos de The French Revolution, são de nossa autoria. 
No ano de 1837, Carlyle traz a lume sua obra mais notável, The French Revolution, imediatamente saudada pela intelectualidade britânica como novo épico do vernáculo inglês. (SYMONS, 1952, p. 147-60 e HEFFER, 1996, p. 144-73). Alquimia explosiva de história, profecia e drama, o livro proporciona ao público não apenas relato fascinante da gigantesca comoção social em território francês, como, igualmente, explicação singular da aventura humana. Inspirado nos românticos alemães e nos historiadores britânicos da literatura, Carlyle adota visão evolutiva da história, permeada pela alternância secular entre períodos de avanço e declínio da espiritualidade, interrompidos, ocasionalmente, pela erupção de avassaladora força destrutiva, a extinguir todas as coisas corroídas pelo tempo de modo a trazer o renascimento (palingenesis) da humanidade para nova era de fé. (WELLECK, 1944 e VIDA, 1995, p. 137-63). Tal concepção é elaborada em diversas passagens de The French Revolution, como, por exemplo, no capítulo em que Carlyle se reclina a meditar sobre o trágico destino de Luís XVI:

"Como tais ideais se realizam e crescem maravilhosamente, de entre o caos flutuante e incongruente donde brotam, é o que a História, se nos quer ensinar alguma coisa, tem de nos dizer. Como eles nascem e, depois de longo e tormentoso crescimento, florescem exuberantemente, para, enfim, rapidamente (porque a floração é breve) começarem a declinar, encarquilhando-se e caindo aos bocados, até desaparecerem ruidosa ou silentemente. A florescência dura tão pouco! É como a de algumas flores do cacto secular que, depois de um século de espera, se abrem apenas por horas.” (1837, p. 44).

Com essa teoria do processo histórico em sua retaguarda, Carlyle póe-se a descrever, em termos contundentes, a longa e convulsiva agonia de morte da sociedade aristocrática francesa, incinerada nas chamas impiedosas da revolução, a fim de, sobre as cinzas do passado, serem fincadas as pilastras do futuro: "As fontes da grande profundura efervescem; fontes de fogo, envolventes, engolfantes", assim anuncia Carlyle a explosão vulcânica das monstruosas forças sociais represadas no correr de séculos, ao que, completa: " $A$ vossa película de terra desfaz-se, ficando submergida; e, em vez dum mundo verde e florido, fica um caos de assolação, em revolvimento louco; o qual tem de novo, com tumulto e luta, de se fazer num mundo." (1837, p. 68). O aspecto mais impressionante desse cataclismo anárquico descrito por Carlyle reside em sua convicção, já manifesta em On history, de que reis, nobres, clérigos, generais, parlamentos, Assembléias e Convenções nada representaram de substancial nos rumos do processo revolucionário, resumindo-se, antes, a espumas vazias, vagando ao acaso na superfície de águas profundas a se retorcer violentamente. 
O quanto Carlyle distancia-se, assim, da visão convencional sobre o assunto prevalecente na Inglaterra à época pode ser aquilatado por meio de rápida referência à interpretação dos eventos revolucionários desenvolvida pelo influente político e escritor britânico Edmund Burke em seu livro Reflections on the Revolution in France, publicado em 1790. De acordo com esse autor, a Revolução é estigmatizada como um exercício de tirania originado na equivocada convocação dos Estados Gerais, especialmente do Terceiro Estado, composto em grande número por advogados e rábulas provinciais, predispostos ao litígio e sem qualquer experiência administrativa ou política. Enquanto o país encontrava-se em paz e próspero economicamente, sustentava Burke, os sediciosos revolucionários, inspirados nas teorias iluministas sobre os direitos dos homens, ter-se-iam aproveitado da ingenuidade do Soberano para promoverem a devastação da propriedade e da economia nacional. "Eles não incorreram em sacrifício na implantação de seus projetos [... en enquanto aprisionavam seu Rei, assassinavam seus concidadãos, banbando em lágrimas e arremessando na miséria e no sofrimento milhares de valorosos homens e suas familias." (BURKE, 1790).

Retornando, então, a Carlyle, pode-se indagar aqui: se todos aqueles considerados os principais personagens e instituiçôes da França revolucionária apenas se digladiavam na remota estratosfera do mundo real, onde, então, para ele, ocultava-se a força motriz que imprimia rumo aos acontecimentos? Quem, ou o quê, comandava a Revolução, se não era ela apenas levante desordenado no mais alto grau, agitação de gananciosos e despreparados, como pretendia Burke? A fim de melhor nos acercarmos da resposta, é preciso ter em conta que, na história narrada por Carlyle, a guerra civil francesa assume, desde o início, duas ramificações principais: a verbal, regida pela "lógica parlamentar", e a manual, travada com "aço nos campos de batalha". Na primeira, nenhuma vitória ou conquista afigurar-se-ia duradoura: "Batei o vosso adversário com a invectiva parlamentar, até que ele fique sem sentidos; cortai-o em dois [...] isso de pouco vale; amanhã recomeça o seu fogo!" Na segunda, porém, estender-se-ia a arena na qual tudo se definiria. Nela, garante o escocês, “... um golpe bem assestado é decisivo; porque, fisicamente falando, quando se the fazem saltar os miolos, o homem morre honestamente, e não mais vos incomoda." (1837, p. 214, 282).

A Assembléia Nacional, santuário iluminista onde a democracia é convidada a salvar a nação, rapidamente degenera, no linguajar sarcástico de Carlyle, em estridente confusão sonora, dilúvio de "lugares-comuns" e de "conjugação de verbos defectivos" em meio ao qual o silêncio parece "a única benção da vida". O resultado disso, a primeira, e brevíssima, Constituição da França, é prontamente desqualificada por ele como reles magote de papel, ingênuo contrato social inspirado no "Evangelho de Rousseau", sem 
a menor correspondência com as necessidades e anseios da população. "Pode-se arquitetar uma Constituição e até bastantes Constituiçôes a la Siéyes", 6 ironiza o profeta, "mas a dificuldade tremenda é a de arranjar homens para viverem nelas!” (1837, p. 208, grifos no original).

Por outro lado, é preciso ter presente que a convulsão social francesa, como a entende Carlyle, é, antes de tudo, o erigir concreto de um novo mundo. Daí que a violência indiscriminada, face mais radical da ação revolucionária, seja acolhida por ele como força determinante de todos os eventos cruciais que impulsionam a Revolução à frente. As matanças e chacinas do período, por mais repulsivas que pudessem parecer aos analistas da época, explica a certa altura Carlyle, eram usualmente condenadas, sem reflexão ulterior, por constituírem-se em atos espontâneos de um episódio singular. Já as guerras, muito mais devastadoras, convertiam-se em objeto tradicional de idolatria apenas por serem costumeiras. "Enquanto [...] a revolução, menos freqüente que guerra, não tem as suas leis de revolução, os individuos de pano grosseiro são não-costumários” e, justamente por isso, adverte Carlyle, "amados irmãos que gritais [diante da violência] fechemos essas nossas bocas abertas e, deixando de gritar, comecemos a considerar.” (1837, p. 552). Ao divisar a História como processo evolutivo, mas, também, degenerativo das estruturas sociais, Carlyle eleva a ruptura da ordem à condição de etapa normal e, acima de tudo, indispensável ao renascimento da sociedade. Por conseguinte, para ele, a ferocidade revolucionária, como nota Rosenberg (1985, p. 95), “... não é aberração passageira, mas processo recorrente e inevitável e, portanto, além de qualquer juizo moral categórico.”

Retornando à pergunta original: quem, então, na França conflagrada, empunha a arma imbatível e mostra deter, de fato, como corrige Carlyle, os "poderes" - ao invés dos "deveres" -, do homem? A revolução do calvinista escocês, a do tipo feita à mão, na ponta dos chuços e dos mosquetes, é aquela que brota dos subterrâneos das cidades e se afirma na queda da Bastilha, na marcha das mulheres sobre Versalhes, na tomada das Tulherias, na resistência aos invasores austríacos, no reinado do Terror, enfim, em todos os momentos nos quais a força é convocada a atropelar o discurso. "Em geral", responde Carlyle, "não podemos nós dizer que a Revolução Francesa se encontra no coração e na cabeça de todo o francês de fala violenta, ou que pensa com a violência?” (1837, p. 207). Tal asserção, contudo, não significa apenas força bruta conduzida por turba enlouquecida, pois a população francesa, massacrada pela fome, pela injustiça e pela falsidade - essência do sanscullotismo a se nutrir "com aquilo de que outras coisas morrem" -, é que se agiganta como protagonista central no imenso painel revolucionário de Carlyle. As massas, nesse grande afresco, irrompem como manifestação da vida cósmica universal, única rocha de sinceridade e realismo num oceano de hipocrisia e traição, e que fazem

6 Emmanuel Joseph Siéyes (1748-1836), ou Abbé Siéyes, defensor dos ideais iluministas e monarquista constitucional, eleito deputado pelo Terceiro Estado de Paris e, em 1790, presidente da Assembléia Nacional. 
marchar as coisas enquanto vige em França o direito à insurreição. Longe, porém, de significar legitimação da anarquia, esse direito teria suas raízes lançadas fundo no solo francês, mais precisamente nas milhares de sociedades jacobinas espalhadas por todos os cantos da nação:

"Eis a verdadeira Constituição, feita não pelos mil e duzentos augustos senadores, mas pela própria natureza, e que brotou inconscientemente das necessidades e dos esforços destes vinte e cinco milhões de homens. Eles são os "Senhores dos Artigos", os nossos jacobinos; originam debates na Legislativa, discutem guerra e paz; decidem antecipadamente o que a Legislativa tem de fazer [...] os vossos outros poderes aqui são simulacros: este poder é-o de facto.” (1837, p. 463, grifos no original).

O próprio jacobinismo, todavia, esclarece Carlyle, sustenta-se somente enquanto existem coisas a morrer. Ou, ainda, enquanto é preciso confiscar, tributar, expropriar e, primordialmente, exterminar os inimigos da República. Rechaçados, porém, os invasores estrangeiros e passada a fúria do Terror, após milhares ceifados pela guilhotina e outros tantos abarrotarem as masmorras, os traidores da pátria já não mais despertam alarme. A opinião pública, sufocada pelo banho de sangue, determina chegada a hora de os líderes jacobinos fitarem, também, a retina fria do carrasco. O sanscullotismo, agora desprovido de sua espada, não tardará a se recolher aos subterrâneos, batido pela mesma força com a qual derrubara prisões, reis e constituições. Quando, em outubro de 1795, o jovem oficial Bonaparte, a mando da Convenção, dispara os canhôes contra os rebeldes da seção Lepelletier, em Paris, é findo, de fato, o direito de insurreição. Com ele, Carlyle considera encerrar-se, de vez, a Revolução Francesa.

Nesse instante, contudo, a palingenesis se completa. A revolta e a morte já não imperam soberanas. Nasce, enfim, o novo mundo! Carlyle, todavia, não vê aí, nessa realidade que se impõe, senão a ascensão de outra aristocracia, distinta, sim, daquela que se foi, mas cuja única virtude residiria em seu poder de estabelecer a ordem em meio ao caos: "E agora, por curso natural, chegamos à aristocracia do cofre", admite desesperançado. "É o curso que todas as sociedades européias, na presente hora, seguem. Não será uma espécie mais baixa de aristocracia? Infinitamente mais baixa; a mais baixa até hoje conbecida." (1837, p. 757). E exatamente esse arranjo social que se consolida no período pós-revolucionário - o capitalismo - é que virá a se converter no alvo contra a qual Carlyle direciona todo poder de sua eloqüência ao confrontar a economia da Inglaterra em que vive. 


\section{PROFECIA, CAPITALISMO E REDENÇÃO}

Se na reconstituição da Revolução Francesa Carlyle obrigara-se a ajustar seu estilo literário à interpretação de eventos passados, o quadro configura-se radicalmente distinto quando o foco de sua preocupação se desloca para a situação social da Inglaterra vitoriana. Ali, onde discute o presente e, sobretudo, o futuro da nação, encontra ele oportunidade ímpar para exercitar seus dotes proféticos. Cumpre notar, porém, desde logo, não ser à consciência racional que ele se dirige, procurando demonstrar ou convencer, mediante concatenação coerente de argumentos abstratos, a veracidade de suas proposições. Ao contrário, sua preleção é, essencialmente, apelo ao inconsciente, esforço de persuasão com o intento de aguçar a percepção crítica de fatos tidos por triviais. Ou, como sintetiza Holloway (1965, p. 9), fazer “... com que coisas antigas fossem vistas de uma nova maneira." Para tanto, Carlyle virá resgatar o ancestral padrão discursivo dos profetas hebreus, com o qual se familiarizara desde cedo, e estruturado, basicamente, em quatro movimentos, a saber: (i) a denúncia incisiva de situação alarmante a afligir a sociedade; (ii) a revelação das razões ocultas ou negligenciadas do problema; (iii) a promessa de calamidades ainda maiores caso a questão apontada não viesse a ser devidamente resolvida e; (iv) o caminho correto para evitar-se a perdição coletiva. (LANDOW, 1986).

Desse modo, já em Signs of the times, Carlyle alerta para a hegemonia avassaladora da lógica mecanicista sobre todas as esferas da vida social, a "Era da Maquinaria", em meio à qual a economia, a política e a religião estariam integralmente regidas pela arte de "adaptar os meios aos fins". Essa nova era, apesar disso, não seria despojada de aparentes benefícios para todos:

"Que maravilhosas conquistas têm sido assim adicionadas, $e$ ainda $o$ são, ao potencial físico da bumanidade; quão melhor alimentado, vestido, alojado e, em relação a todos os aspectos externos é, ou pode ser, agora atendido o homem por um certo volume de trabalbo, é reflexão gratificante que se impõe a todos.” ([1829] 1950, p. 23).

De maneira análoga, encontramos Carlyle a exaltar a imensa afluência material da Inglaterra, seus campos, colheitas, indústrias e população, na abertura de Past and present:

"Com incansável generosidade a terra da Inglaterra brota e cresce; ondulando com douradas colheitas; repleta de fábricas, implementos industriais e quinze milhões de trabalhadores, conhecidos como os mais fortes, argutos e dispostos que a Terra já possuiu.” (1843, p. 1). 
Por mais agradáveis as imagens que tais palavras façam aflorar à mente, apressa-se Carlyle em prevenir, acobertavam elas anomalias incomensuráveis, a se desenvolver livres nas entranhas da sociedade e, regra geral, ignoradas por todos. Em Signs of the times, os malefícios da cultura mecanicista decorreriam, essencialmente, da dissociação entre os planos interior e exterior da existência individual. A fabulosa ampliação dos poderes de transformação da Natureza, aliada à busca desenfreada pelos prazeres imediatos, haveria suprimido o impulso espiritual do homem. No âmbito da fé cristã, a religião convertera-se em mero cômputo racional, troca de certo montante de prazeres terrenos por quinhão maior no paraíso celestial. O reino intelectual, por sua vez, perdera-se na submissão ao argumento formal e científico, sem ousar atrever-se nos mistérios do insondável ou, como sugeriam os românticos alemães, na beleza e na sabedoria latentes no universo transcendental. A moralidade, de forma similar, deixara de guiar-se por princípios de ordem superior, inatos ao homem, para reduzir-se a consideraçóes de caráter estritamente mundano e utilitário. A virtude, deplora Carlyle, “... não é mais a reverência pelo Belo e Bom, apenas cálculo do que é Lucrativo” ([1829] 1950, p. 36) ou, ainda:

"Por nossas habilidades em Mecanismo, ocorre que, na administração das coisas materiais, superamos todas as evas, enquanto que, a tudo que se refere à pura natureza moral, à verdadeira dignidade de alma $e$ caráter, estamos, talvez, em condição inferior à maioria das eras civilizadas.” ([1929] 1950, p. 35).

Em Characteristics, a enfermidade oculta do mundo vitoriano decorreria da circunstância de a verdadeira sociedade, entendida por Carlyle como unidade formada pela congregação de indivíduos em torno de certa idéia transcendente comum, já não mais existir enquanto tal. Ao reverso, encontrar-se-ia ela, no presente, totalmente destruída, devastada pela investigação sistemática de sua natureza, a sinalizar estado congênito de incredulidade e dúvida sobre a efetiva sanidade da organização social. Nesse ponto, entretanto, Carlyle avança em seu libelo acusatório, apontando, para lá da indigência espiritual do homem contemporâneo, a miséria prevalecente no mundo material. Milhôes de indivíduos - sob o olhar impassível de sua elite dirigente - estariam a se arruinar na mais abjeta penúria, precisamente numa etapa da civilização sem paralelo na abastança de riqueza: "Ele [o homem] subjugou esse Planeta, sua moradia e herança, mas, a despeito disso, não colbeu nenhum lucro da vitória", recrimina Carlyle a barbárie da sociedade moderna. E prossegue: "Os deuses desse mundo terreno sentam nas alturas de seus tronos resplandecentes [...] enquanto o infinito caos vivo da Fome e da Ignorância se revolve terrivel, em fúria sombria, aos seus pés.” (1831). 
No ano de 1839, em seu opúsculo Chartism, Carlyle volta a tratar daquela que, em sua opinião, convertera-se na grande chaga da Inglaterra vitoriana: o infortúnio da classe trabalhadora britânica. Embora, nessa ocasião, as reivindicações dos chartistas já tivessem sido repelidas pelo Parlamento, Carlyle contesta a alegação de, com isso, ter-se sepultado o ímpeto do movimento. Antes, insiste que as razões últimas da insatisfação popular, as desumanas condições de existência das camadas operárias, perpetuar-se-iam vivas enquanto não fossem tratadas com a devida responsabilidade por parte das classes governantes do país. O tema, em verdade, não era de todo ignorado na literatura econômica. Entre os autores britânicos que já haviam se ocupado com o problema, alguns, os críticos do capitalismo, enxergavam no artesão e no camponês do passado um trabalhador em melhor situação do que os assalariados modernos. Por outro lado, os otimistas, partidários da industrialização, advogavam que o processo de crescimento econômico, cedo ou tarde, acabaria por distribuir seus ganhos para todas as classes sociais dispostas a esperar. Já na teoria dos economistas clássicos predominava a tese malthusiana de ser a miséria da população ocasionada por seu impulso incontrolável à procriação, porquanto sempre que seus rendimentos experimentassem melhora, sucederia aumento demográfico que empurraria os salários de volta ao nível de subsistência. (SUPPLE, 1978, p. 64-9 e O'BRIEN, 1989, p. 87-100).

Numa célebre e contundente passagem de Chartism, um Carlyle de todo exasperado proclama ser o estado deplorável dos pobres, por ele designado a "Questão sobre a Condição da Inglaterra”, o mais urgente assunto a ser discutido, de imediato, pelo novo e reformado Parlamento britânico:

"A condição da grande massa da população de um pais é a condição do próprio pais; isso, direis, é um truismo em todos os tempos; um truismo, sim, que urge ser reconbecido como verdade, nesse exato momento, e sobre o qual há que se intervir, no tempo atual. Não obstante, leiam-se os debates registrados no Hansard's, ou nos jornais matutinos, caso não se tenha nada mais a fazer! [...] a questão do Canadá, da Irlanda, da Índia-Oriental, questões intimas da Rainha; leis do jogo, dos juros; negros africanos, trabalhadores asiáticos, gado de Smithfield, carruagens, - questões e temas de todos os matizes, exceto, simplesmente, esse alfa e ômega de tudo o mais! Certamente os Honoráveis Membros devem falar também sobre a Condição-da-Inglaterra [...] Não estão eles lá, por negociação, missão e expressa indicação deles mesmos e de outros, para falar pelo bem da Nação Británica? Qualquer que seja o grande interesse británico que venham a tratar, esse, acima de todos, estão eles conclamados a debater. Ou são eles porta-vozes da grande, 
muda e exausta classe que não pode se pronunciar, ou são coisa nenhuma que se possa especificar." ([1839] 1950, p. 262).

Tendo acompanhado como Carlyle organiza suas idéias no primeiro ato de seu discurso, desvendando o mal onde antes parecia somente existir o bem, é possível, então, adentrar o segundo estágio de sua locução profética, quando a fonte da grande moléstia da sociedade britânica é identificada na renúncia absoluta aos valores do mundo transcendental. Ao término de Signs of the times, por exemplo, encontra-se o seguinte lamento: "Estão os templos solenes, nos quais a Divindade, no passado, revelava-se visivelmente entre nós, se desfazendo em ruinas? Nós podemos repará-los, nós podemos reconstrui-los." ([1829] 1950, p. 42). Novamente, em Characteristics, o leitor é confrontado com a interessante combinação entre idealismo alemão e hebraísmo bíblico quando assevera Carlyle que “... a desordem Física da Sociedade não é senão reflexo e impressão da desordem Espiritual", aduzindo, poucas linhas à frente: "Examinai o mundo interior do homem, em qualquer uma de suas relaçóes e performance sociais, aqui também tudo parece autoconsciência enferma, colisão e luta mutuamente destrutiva." (1831). Por fim, com Past and present, idêntico argumento viria a ser introduzido da forma mais direta possível: "Fechamos quietos nossos olhos para a Substância eterna das coisas, e os abrimos apenas para as aparências ilusórias e imitações das coisas.” Aí, para Carlyle, encontrar-se-ia a razão de toda a crise moral e material de seu tempo: "Este é, verdadeiramente, o foco da praga; centro da universal Gangrena Social, ameaçando todas as coisas modernas com morte abominável.” (1843, p. 137).

Com isso, chegamos ao terceiro ato do drama profético de Carlyle: o vaticínio de calamidade iminente caso não se corrigissem os descaminhos da sociedade. Nesse momento, o escocês invoca um de seus mais caros princípios na explicação da dinâmica social moderna, já explorado em The French Revolution, a saber, “... o direito de um povo rebelar-se contra prolongada opressão", como lembra sucintamente Roe (1921, p. 75). Com efeito, em Chartism consta que, apesar de ser o homem resistente a todo tipo de desapontamento, infelicidade e trabalho estafante, nele sobreviveria indignação perene com a injustiça: "Se os homens perderam sua crença em Deus, seu único recurso contra o NãoDeus, de Necessidade e Mecanismo [...] é, com ou sem esperança, - a revolta." ([1839], 1970, p. 272, grifos no original). Nesse sentido, em Signs of the times, Carlyle já anunciava acercar-se da Inglaterra estação inclemente, soprada pelos ventos de rebelião contra o domínio do pensar e fazer mecanicista:

"O tempo é doente e desconjuntado. Muitas coisas atingiram seu climax; e existe um velho adágio a nos contar que "a hora sombria é próxima do amanhecer" [...] As mentes pensantes de todas as nações imploram por mudança. Há embate profundo em todo o tecido da soci- 
edade; colisão infinita do Novo com o Velho. A Revolução Francesa, como é hoje bastante visivel, não foi parteira desse grande movimento, mas seu rebento [...] a questão final não se resolveu naquele pais; nem está ela resolvida, ainda, em lugar algum." ([1829] 1950, p. 43).

Numa versão mais refinada dessa terceira fase de seu discurso, o aviso de tragédia coletiva à espreita, Carlyle, num dos capítulos iniciais de Past and present, serve-se do milenar mito da esfinge como representação do dilema mortal diante do futuro da Inglaterra. Se não lograsse ela responder adequadamente ao grande enigma de seu tempo - o estabelecimento de verdadeira justiça entre os homens -, a sorte do Reino, em breve, tomaria a forma de retumbante colapso social. Em sua direção o país estaria sendo empurrado, inexoravelmente, pelas colossais forças da dissolução e da desordem, inscritas a ferro e fogo nas eternas leis da Natureza. O fim do caminho encontrar-se-ia à vista. As mais veneráveis instituições nacionais, o Parlamento e as Cortes, outrora sustentáculos da sociedade na travessia dos séculos, estariam a "acariciar a destruição em seu colo" a cada minuto em que se mantinham apegadas ao passado. O conservador, garante Carlyle com voz tonitruante, pode ser útil em certas condiçôes e durante certo período, mas somente “... até que tudo isso termine. Até que as amargas necessidades dos homens não vos agüentem mais. Até que a paciência da Natureza convosco se vá; e não exista mais estrada ou chão, e se escancare a garganta do abismo." (1843, p. 17, grifos no original).

Havendo, assim, propalado em alto som os males da condição social da Inglaterra e os perigos que daí poderiam advir, Carlyle introduz, então, o ato derradeiro de seu percurso profético: a indicação do caminho para a salvação da sociedade. Mas não o faz sem, antes, descartar as falsas promessas de redenção de seu tempo. A primeira delas, o laisser faire, como explica em Chartism, reduzir-se-ia à admissão categórica, por parte das classes dirigentes, de serem elas incompetentes para governar a nação. E, não fosse isso o bastante, de que as relações humanas também dispensariam qualquer tipo de orientação, justamente numa etapa histórica na qual, segundo Carlyle, se mostrava inadiável a intervenção do governo em benefício das hordas de desvalidos. Contra o individualismo do laisser faire, relata ele, ainda em Past and present, o caso de uma viúva pobre que, tendo procurado em vão auxílio nas instituiçôes de caridade de Edimburgo, acabara por contrair tifo e morrer, contaminando, porém, nesse ínterim, dezessete cidadãos da cidade: "Mas ela, assim, provara sua irmandade; sua febre tifóide matara-os; eles, de fato, eram seus irmãos, embora negando tal fato.” (1843, p. 162).

A democracia, por sua vez, segunda falsa promessa de redenção, nada teria a oferecer de tangível às massas do país. Para o calvinista escocês, avesso a controvérsias e especulações, redundaria ela inútil numa sociedade em que o governo, de qualquer maneira, 
era suposto existir apenas para manter-se inativo em prol do bem geral dos negócios. Do Parlamento, templo supremo da discussão e da retórica, ou seja, de tudo aquilo que Carlyle repudiava, pouco se poderia esperar no tocante à modificação da sociedade. A noção comum de liberdade, traduzida no direito de cada eleitor possuir parte infinitesimal de responsabilidade em um "tagarela eleito para o parlatório nacional", embora atraente para muitos, seria inteiramente falaciosa. Seu significado efetivo resumir-se-ia ao isolamento irrevogável de todos entre si, até restar, somente, o laço social dos pagamentos em dinheiro (cash nexus), negação absoluta do genuíno convívio social produzida pelo primado do laisser faire. Nessas circunstâncias, a liberdade burguesa, para milhões de trabalhadores britânicos, representaria nada além de seu já consumado direito à fome e à falta de trabalho. "A Democracia, pelo que se sabe", escreve Carlyle com desdém, "nunca se mostrou capaz de realizar muita coisa, que não a destruição de si própria.” ([1839] 1950, p. 283). ${ }^{7}$

Como, então, afinal, seria o novo mundo capaz de debelar a terrível ameaça de comoção social alimentada dia a dia pela iniqüidade do capitalismo industrial britânico? $\mathrm{O}$ impetuoso Carlyle, nesse instante crucial de seu discurso, revela-se demasiadamente receoso em aventurar-se no terreno do amanhã, recusando-se a adiantar algo mais do que um esboço do futuro imediato a ser perseguido. Não obstante, vale a pena inspecionar o que nos diz a esse respeito. Ao longo de Past and present, professa ele, inicialmente, a necessidade de criar-se um organismo estatal de saúde pública encarregado de limpar as cidades, construir parques e implantar condições salutares nas fábricas, de forma a propiciar vida mais digna às futuras geraçôes do país. Além disso, é enfático ao clamar aos legisladores prioridade à educação universal, de modo a permitir o florescimento das faculdades intelectuais dos milhões de trabalhadores britânicos, tema ao qual já fizera referência em Sartor Resartus:

"Que deva um Homem morrer ignorante tendo capacidade para o Conbecimento, a isso chamo uma tragédia, como parece ocorrer, em verdade, mais de vinte vezes a cada minuto, segundo certos cálculos. A infima fração da Ciência que o conjunto da Humanidade, num vasto Universo Incógnito, adquiriu, por que não é isso, com extrema diligência, colocado ao alcance de todos?” ([1833] 1915, p. 42).

7 A oposição ao avanço da democracia na Inglaterra vitoriana não era característica exclusiva de Carlyle. Diversos pensadores de renome, especialmente os liberais, com destaque para Stuart Mill, temiam que, com o sufrágio popular, viessem, inevitavelmente, o abuso de poder, a tirania das massas e a eliminação das liberdades individuais. Em virtude desses temores, caberia aos conservadores Tories a ousadia de aprovar a ampla reforma eleitoral de 1867, bem mais arrojada do que todas as anteriores propostas pelos Whigs (cf. ROACH, 1957 e HIMMELFARB, 1995, p. 333-92). 
Conjuntamente, continua Carlyle, deveria o governo instalar um completo sistema de imigração a fim de permitir aos desempregados o povoamento de terras distantes, o que, acessoriamente, viria a estimular o comércio do Reino com suas colônias. Todas essas medidas, indispensáveis à regeneração da Inglaterra, somente poderiam proceder da intervenção estatal, baseada em decisão firme dos legisladores e das autoridades, única alternativa para superar a anarquia derivada do império da oferta e da demanda: "A interferência já comecou, precisa continuar, precisa ampliar-se extensivamente, aprofundar-se e aguçar-se", lê-se em Past and present. (1843, p. 262).

Mas, como o próprio Carlyle admite, nem tudo poderia ser resolvido pelo governo. No campo econômico, propriamente dito, o problema da "organização do trabalho" apareceria a ele como a principal tarefa do futuro. Nesse aspecto, informa o profeta, duas medidas poderiam ser consideradas fundamentais: a primeira delas, a eliminação da extrema instabilidade na relação assalariada. Para atingir esse objetivo, a construção de hospitais e a instituição de pensões, promoçôes e contratos de trabalho duradouros contribuiriam no desenvolvimento de um sentimento de lealdade do trabalhador para com a empresa: "Alguma permanência nos contratos já é quase possivel [...] Uma vez garantido isso, a base de todos os bons resultados estará lançada.” (1843, p. 278). Quanto à segunda medida, consistiria ela no envolvimento direto do trabalhador com os destinos do empreendimento, mediante sua participação nos ganhos de modo a fazer da produção negócio conjunto entre patrôes e empregados. (1843, p. 279). Quão interessante, arrisca Carlyle a prognosticar, não seria a empresa do futuro na qual “... todos os homens, desde o capitão da induistria até o mais baixo supervisor e operário [estivessem], economicamente, bem como por lealdade, compromissados com ela?" (1843, p. 281-2).

A despeito de sua cautela, Carlyle não evita certas incoerências quando arremessa a vista num horizonte mais largo, discorrendo sobre a quem caberia a missão de dar forma concreta à sociedade do porvir. De uma parte, em Past and present, entoa louvor à "nobreza” do trabalho, elevando os operários industriais à condição de cavalheiros (chivalry of labour) dos novos tempos:

"Acordem, vocês, nobres Trabalhadores, guerreiros da luta verdadeira: tudo isso precisa ser consertado. São vocês que já estão meio-vivos quem eu sauido a ingressar na vida, quem eu conclamo, em nome de Deus, a sacudir longe seu sono enfeitiçado e a viver plenamente [...] Deixem o bucaneirismo afastar-se de vocês; alterem e, rapidamente, revoguem todas as leis dos bucaneiros se quiserem lograr qualquer vitória duradoura." (1843, p. 279). 
A afinidade de Carlyle com os trabalhadores, entretanto, não significa que eles, na condição de classe social majoritária, devessem perseguir sua emancipação completa do capitalismo, como advogaria, adiante, o discurso socialista. Muito ao contrário. Em vez de uma política das massas, Carlyle apela, com maior veemência, à sua peculiar veia autoritária calvinista. A sociedade ideal, na imaginação do escocês, seria aquela governada por uma aristocracia de sábios, aptos a desempenhar sua liderança de forma generosa, ainda que com mão de ferro, os quais os homens comuns deveriam reverenciar e obedecer cegamente, à semelhança do pastor e seu rebanho na diocese presbiteriana de sua infância. De fato, em determinada passagem de Chartism, e cada vez mais intensamente com o passar dos anos, Carlyle mostra-se francamente favorável a esse arranjo social de inspiração teocrática, único com potencial, segundo ele, de conciliar a verdadeira liberdade espiritual interior com o imperativo de disciplina e dedicação fiel ao trabalho:

"Certamente, de todos os "direitos do homem", esse direito de o ignorante ser guiado pelo inteligente, de ser, de forma gentil ou forçada, mantido no devido curso por ele, é o menos sujeito à disputa. A própria Natureza ordena assim desde o princípio; a Sociedade luta rumo à perfeição ao realizar e alcançar isso mais e mais. Se a liberdade tem algum significado, ele quer dizer o desfrute desse direito.” ([1839] 1950, p. 283 , aspas no original).

\section{CONSIDERAÇÕES FINAIS}

A doutrina social de Carlyle, como visto, emerge da síntese de três vertentes fundamentais do pensamento ocidental de seu tempo: o puritanismo anglo-saxão, o idealismo germânico e a prática revolucionária francesa. Nessa síntese peculiar entre tradições religiosas, filosóficas e políticas tão distintas e, por conseguinte, propensa a toda a sorte de contradição, despontam, não obstante, traços de modernidade no pensamento do profeta escocês. O primeiro deles, a percepção que demonstra possuir daquilo que Williams (1961, p. 287-301) assinala como o principal fenômeno da era moderna: a ascendência das massas ao centro da vida social das naçóes. Que tenha Carlyle logrado exercer profunda influência nos meios políticos e intelectuais da época é prova não apenas do vigor de sua retórica inovadora, mas, essencialmente, de sua obstinação em reorientar o debate público para a condição material e espiritual da população britânica, alertando para a capacidade da mesma em subverter a ordem de coisas existente. Mas, se sua cepa calvinista lhe abre os olhos para as misérias e potencialidades do trabalhador sob a nova ordem capitalista, é ela também que o impede de sequer entrever as possibilidades de reforma social inscritas no lento, mas pro- 
gressivo, movimento de ampliação da democracia no país. A política parlamentar, do tipo que se constrói na Inglaterra do século dezenove, aparece, assim, a Carlyle, apenas como o domínio por excelência de inócuo embate verbal, negação última do próprio ato de governar sob a tutela da doutrina liberal e impotente, portanto, para qualquer ação efetiva de transformação estrutural da realidade. Daí que, para ele, a força das massas estivesse confinada unicamente à revolta, ao estilo francês, operando o nascimento de um novo mundo cujo destino, no entanto, lhes escaparia às mãos, reservado a uma confraria de sábios bem intencionados, os heróis dos novos tempos.

O segundo aspecto de modernidade na obra de Carlyle surge em sua concepção de uma história - em seu passado, presente e futuro -, inteiramente forjada pela ação humana. O Deus transcendental, vida cósmica universal a que tantas vezes se refere em seus textos - influência do idealismo alemão - termina por se mostrar, paradoxalmente, de todo ausente nos negócios humanos, "redundância teológica", como define Rosenberg (1974, p. 51), sem a menor interferência na dinâmica social. De acordo com a visão antimecanicista peculiar de Carlyle, o futuro apresenta-se sempre capítulo em aberto, no qual o homem é confrontado com a alternativa de refazer por completo a si e, por extensão, a tudo que lhe cerca, sem que aí se apresente trajeto compulsório rumo a um final preestabelecido. Os três planos verticais da cosmogonia medieval, o celestial, o terreno e o infernal, são condensados por Carlyle num único mundo horizontal, absolutamente humano, e no qual, segundo Behnken (1978, p. 101), o “... reino de Deus se constitui, cresce e se preenche a partir de interesses terrenos." Explica-se, assim, que na concepção social do profeta de Chelsea seja preservada a roupagem do discurso calvinista, despida, contudo, do Deus bíblico onipotente. Em seu lugar, ingressa um ente cósmico transcendental, mas de todo inerte, de modo a reservar ao homem a plena faculdade de perseguir, de tempos em tempos, seu renascimento integral mediante a reconciliação entre os universos interior e exterior de sua existência.

\section{REFERENCIAS}

ALTHOLZ, Joseph L. The mind and art of Victorian England. St. Paul: University of Minnesota Press, 1976.

BEHNKEN, Eloise M. Thomas Carlyle. Calvinist without theology. Columbia: University of Missouri Press, 1978.

BRYSON, Gladys. Man and society. The Scottish inquiry of the eighteenth century. Princeton: Princeton University Press, 1945.

BURKE, Edmund. [1790] Reflections on the Revolution in France. Disponível em $<$ http://userweb.port.ac.uk/ andressd/frlinks.htm >. Acesso em 28 de dezembro de 2003. 
BURROW, J. W. Faith, doubt and unbelief. In: LERNER, Laurence (org.), The Victorians. The context of English literature. New York: Holmes \& Meier, 1978.

CARLYLE, Thomas. [1829] Signs of the times. In: SYMONS, Julian (org.), Carlyle. Selected works, reminiscences and letters. Cambridge: Harvard University Press, 1970.

. [1830] On history In: SYMONS, J. (org.), Carlyle. Selected works, reminiscences and letters. Cambridge: Harvard University Press, 1970.

. [1831] Characteristics. Disponível em: <http://cepa.newschool.edu/ het/ profiles/carlyle.htm>. Acesso em 15 de janeiro de 2004.

. [1832] James Carlyle. In: SYMONS, Julian (org.), Carlyle. Selected works, reminiscences and letters. Cambridge: Harvard University Press, 1970.

. [1833] Sartor Resartus. In: HEMINGWAY, Samuel B.; SEYMOUR, Charles (orgs.), Selections from Carlyle. Boston, D. C.: Heath and Co., 1915.

. [1837] História da Revolução Francesa. São Paulo: Melhoramentos, Tradução e Prefácio de Antônio Ruas, [s. d.].

. [1839] Chartism. In: SYMONS, J. (org.), Carlyle. Selected works, reminiscences and letters. Cambridge: Harvard University Press, 1970.

. [1843] Past and present. Disponível em <http://www. ajdrake.com/etexts $>$. Acesso em 12 de dezembro de 2003.

CHARLOT, Monica; MARX, Roland (orgs.), Londres, 1851-1901. A era vitoriana ou o triunfo das desigualdades. Rio de Janeiro: Jorge Zahar, 1993.

DEANE, P.; COLE, W. A. British economic growth 1688-1959: trends and structure. Cambridge, Cambridge University Press, 1969.

GOODWIN, Charles J. Carlyle's ethics. International Journal of Ethics, n. 15, p. 198-210, 1905.

HARROLD, Charles F. The nature of Carlyle's Calvinism. Studies in Philology, n. 33, p. 475-86, July 1936.

HEFFER, Simon. Moral desperado. A life of Thomas Carlyle. London: Phoenix Giant, 1996.

HIMMELFARB, Gertrude. Victorian minds. A study of intellectuals in crisis and ideologies in transition. Chicago: Elephant Paperbacks, 1995.

HOLLOWAY, John. The Victorian sage. New York: W. W. Norton, 1965.

HOUGHTON, Walter B. Victorian anti-intellectualism. Journal of the History of Ideas, v. 13, n. 3, p. 291-313, 1952.

IKELER, A. Abbott. Puritan temper and transcendental faith. Carlyle's literary vision. Columbus: Ohio State University Press, 1972. 
LANDOW, George P. Elegant Jeremiahs: the sage from Carlyle to Mailer. Cornell: Cornell University Press, 1986. Disponível em <http://www.victorianweb.org > . Acesso em 27 de novembro de 2003.

MacDONNEL, James. Obituary: Thomas Carlyle. London Times, 1881. Disponível em <http://cepa.newschool.edu/het/profiles/carlyle.htm>. Acesso em 18 de novembro de 2003.

MURPHY, Howard R. The ethical revolt against Christian orthodoxy in early Victorian England. American Historical Review, n. 60, p. 800-17, July 1955.

O’BRIEN, D. P. Los economistas clássicos. Madrid: Alianza Editorial, 1989.

PECKHAM, Morse. Victorian revolutionaries. Speculations on some heroes of a culture crisis. New York: George Brazilier, 1970.

PERRY, Bliss. Carlyle. Indianápolis: Bobbs-Merrill, 1915.

RICKWORD, Edgell. The social setting 1780-1830. In: FORD, B. (org.), The New Pelican guide to English literature. From Blake to Byron. Middlesex: Penguin Books, v. 5, 1982.

ROACH, John. Liberalism and the Victorian intelligentsia. Cambridge Historical Journal, v. 13, n. 1, p. 58-81, 1957.

ROE, Frederick W. The social philosophy of Carlyle and Ruskin. New York: Harcourt, Brace, 1921.

ROSENBERG, Phillip. The seventh hero. Carlyle and the theory of radical activism. Cambridge: Harvard University Press, 1974.

ROSENBERG, John D. Carlyle and the burden of History. Cambridge: Harvard University Press, 1985.

SUPPLE, Barry. Material development: the condition of England 1830-1860. In: LERNER, L. (org.), The Victorians. The context of English literature. New York: Holmes \& Meier, 1978a.

. The governing framework: social class and institutional reform in Victorian Britain. In: LERNER, L. (org.), The Victorians. The context of English literature. New York: Holmes \& Meier, 1978b.

SYMONS, Julian. Thomas Carlyle. The life and ideas of a prophet. New York: Oxford University Press, 1952.

TREVELYAN, George M. History of England. London: Longmans, Green, 1947.

YOUNG, Norwood. Carlyle. His rise and fall. New York: William Morrow, 1927.

YOUNG, G. M. Victorian England. Portrait of an age. London: Oxford University Press, 1960.

WELLECK, René. Carlyle and the philosophy of History. Philological Quarterly, n. 23 , p. 55-76, Jan 1944. 
VIDA, Elizabeth M. Romantic affinities: German authors and Carlyle. Toronto: University of Toronto Press, 1993.

WILLIAMS, Raymond. Culture and society 1780-1950. Edinburgh: Pelican Books, 1961.

E-mail:arthmar.vix@terra.com.br

(Recebido em maio de 2004. Aceito para publicação em novembro de 2004). 